\title{
Continence outcome following needle less operation (vaginal approach) using indigenous mesh
}

\author{
Neelam Goyal ${ }^{1}$, Sanjay Kumar Goyal ${ }^{2} *$
} ${ }^{1}$ Department of Obstetrics and Gynecology, ${ }^{2}$ Department of Urology, Lifeline Hospital and Urology Institute,
Dehradun, Uttarakhand, India

Received: 04 October 2016

Revised: 07 October 2016

Accepted: 12 October 2016

\section{*Correspondence:}

Dr. Sanjay Kumar Goyal,

E-mail: drsanjayuro@yahoo.com

Copyright: (c) the author(s), publisher and licensee Medip Academy. This is an open-access article distributed under the terms of the Creative Commons Attribution Non-Commercial License, which permits unrestricted non-commercial use, distribution, and reproduction in any medium, provided the original work is properly cited.

\begin{abstract}
Background: Economical and accessible non-extensive operation for stress incontinence in women who cannot afford expensive cost of mesh available for mini arc operation and other surgery of incontinences. Inexpensive hernial mesh (Hinglact), commonly available was used after indigenously designing it and placing it without a needle, under the Posterior urethral fascia with a single small vaginal incision.

Methods: The present study was conducted on 25 female patients of post-menopausal group who presented with pure stress incontinence complaints. These patients did not have any uterine descent or previous surgery. Indigenously designed hernia mesh used in place of expensive needled Incontinence Meshes available by a single small incision in posterior urethera area.

Results: Nearly $75 \%$ women with stress Incontinence were relieved of their symptoms with this inexpensive mesh without a needle.

Conclusions: Very effective, inexpensive mesh and surgical procedure for poor socio economic, group of women found to relieve significant Incontinent patients compared to commonly used mesh with a needle.
\end{abstract}

Keywords: Incontinence, Mesh, Urinary

\section{INTRODUCTION}

Urinary Incontinency is a condition of involuntary passage of urine on laughing, sneezing and effort. Women continue to suffer in silence, carrying low selfesteem, conscious of uriniferous smell due to dribbling 2 fear of leaking anywhere anytime on urge. ${ }^{1}$ Apprehensive of extensive surgery and cost involved, many women do not opt for this simple surgery and suffer due to ignorance. ${ }^{2}$ The aim of this study was to cut down cost of Mesh and give better results with inexpensive mesh available for hernia (e.g. Hinlact), without needle and to cut down cost of surgery and stay with low complication rates. $^{3-5}$

\section{METHODS}

Retrospective study of stress incontinence surgeries done on 25 women (post-menopausal), complaining of stress incontinence without any uterine descent/previous surgery, in the year March 2014-March 2016. All these patients were from low socio economic group, women who could not afford expensive mesh available in market for stress Incontinence surgery. All pre-operative parameters and investigations were carried out.

This operation involved a post urethral dissection laterally on both sides, enough to place this indigenously designed piece of mesh (Hinglact), transversely as in 
miniarc operation, closing the vaginal incision and catheterizing the patient for 3 days.

\section{Follow up}

Patients regularly followed up at 1 week, 4 week, 3 months, 6 months and 12 months interval in OPD regarding status of urinary Incontinence (requiring no $\mathrm{pad} / \mathrm{security}$ liners). Data collection done and follow up correspondence conducted in accordance with hospitals ethical guidelines.

\section{RESULTS}

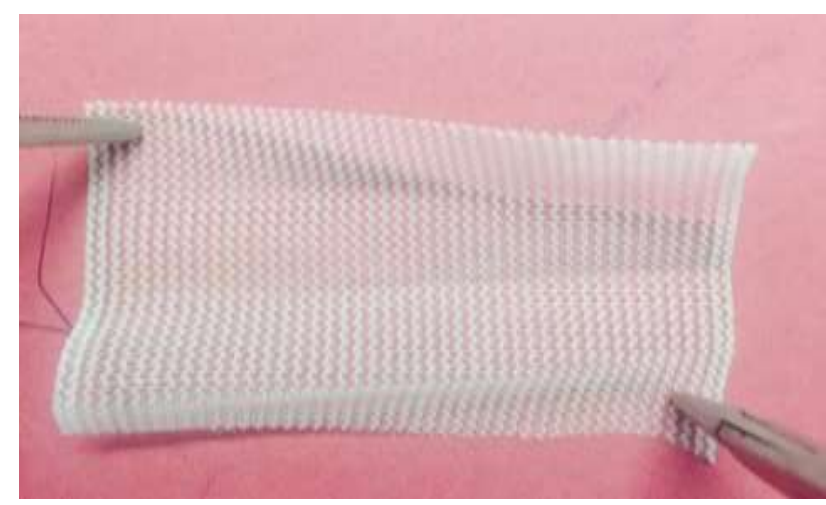

Figure 1: Hernial mesh-Hinglact.

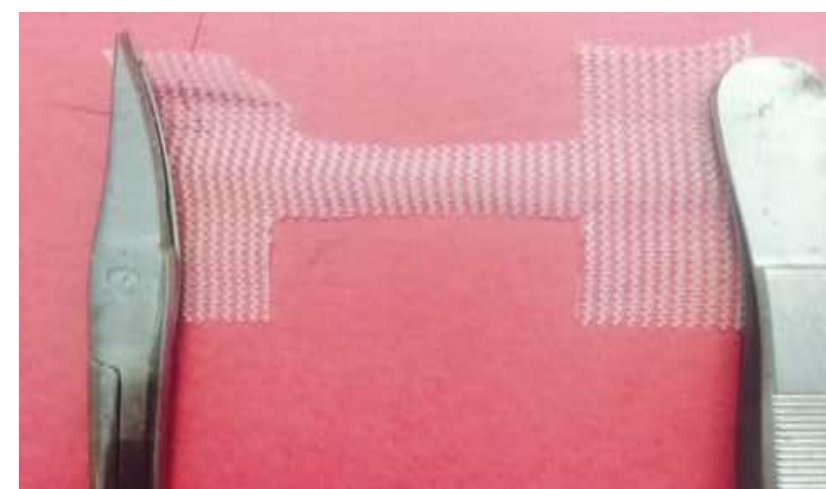

Figure 2: Cut in $\mathrm{H}$-shape design.

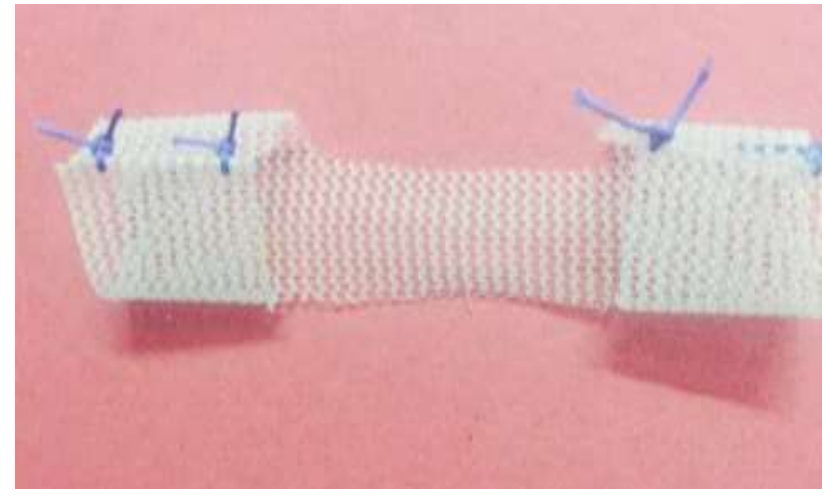

Figure 3: Roll up vertical legs of $\mathrm{H}$ and hold them together.

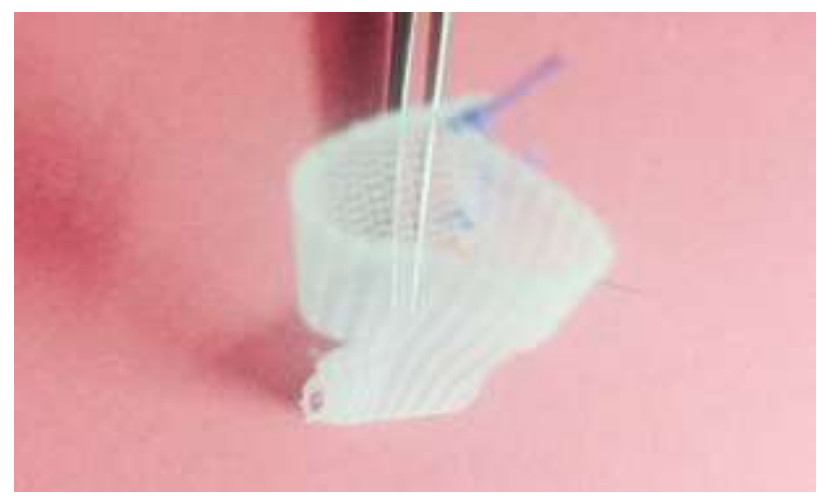

Figure 4: Horizontal leg of $\mathbf{H}$ to be placed behind postr urethral fascia and rolled edges to be in the peri urethral dissected area.

- $\quad$ Out of all 25 patients, 16 were dry after 1 week and they were relieved of their symptoms.

- 2 Patients who had complete open bladder neck were benefitted on day 8 and 3 weeks but after one month of these 2 patients complained of wetness again and needed anticholinergic support which decreased wetness to few occasions.

- 1 patient had partial mesh erosion after one month and the mesh was removed.

Table 1: Distribution of patients according to age groups and postop complaints.

\begin{tabular}{|lllll|}
\hline Age distribution & No. & Follow up complaints & Complications & Complete relief \\
\hline 45 Yrs-55 Yrs & 5 & None & None & 5 \\
\hline 56 Yrs-65 Yrs & 14 & Only 2 had mild wetness & Mild leak in 1 & 14 \\
\hline$>65$ Yrs & 6 & Urge incontinence one & Erosion of mesh in 1 & 5 \\
\hline
\end{tabular}

\section{DISCUSSION}

Stress Incontinence in females is a very common problem and surgery costs around INR 1,00,000.00, the mesh itself being of INR 35,000.00. ${ }^{6,7}$ Lower socio economic patients are not able to afford. This requires low cost alternatives. ${ }^{8-10}$ Indigenously designed piece of mesh cut from ordinary Hinglact mesh placed in post urethral region supporting the facia and placing it without a needle through a single anterior vaginal wal in cison just beneath the uethra and suture with 3-0 vicryl the vertical legs of $\mathrm{H}$ shaped mesh to make both ends circular. ${ }^{11-14}$ 
The Horizontal bar of $\mathrm{H}$ is under the posterior urethera and the vertical rounded legs of $\mathrm{H}$ are in periuretheral dissected area. ${ }^{15}$ Close the vaginal inssicion by $3-0$ vicryl. The results of this surgery are very encouraging, cost effective and easy to afford.

Funding: No funding sources

Conflict of interest: None declared

Ethical approval: The study was approved by the Institutional Ethics Committee

\section{REFERENCES}

1. Chiarelli P, Brown W, McElduff P. Leaking urine: prevalence and associated factors in Australian women. Neurourol Urodyn. 1999;18(6):567-77.

2. Moller LA, Lose G, Jorgensen T. The prevalence and bothersomeness of lower urinary tract symptoms in women 40-60 years of age. Acta Obstet Gynecol Scand. 2000;79(4):298-305.

3. Simeonova Z, Milsom I, Kullendorff AM, Molander $\mathrm{U}$, Bengtsson $\mathrm{C}$. The prevalence of urinary incontinence and its influence on the quality of life in women from an urban Swedish population. Acta Obstet Gynecol Scand. 1999;78(6):546-51.

4. Abrams P, Cardozo L, Fall M, Griffiths D, Rosier P, Ulmsten U, et al. The standardization of terminology of lower urinary tract function: report from the Standardization Sub-committee of the International Continence Society. Am J Obstet Gynecol. 2002;187(1):116-26.

5. Grimby A, Milsom I, Molander U, Wiklund I, Ekelund P. The influence of urinary incontinence on the quality of life of elderly women. Age Ageing. 1993;22(2):82-9.

6. Hunskaar S, Vinsnes A. The quality of life in women with urinary incontinence as measured by the sickness impact profile. J Am Geriatr Soc. 1991;39(4):378-82.

7. Shumaker SA, Wyman JF, Uebersax JS, McClish D, Fantl JA. Health-related quality of life measures for women with urinary incontinence: the Incontinence
Impact Questionnaire and the Urogenital Distress Inventory. Continence Program in Women (CPW) Research Group. Qual Life Res. 1994;3(5):291-306.

8. Vaart CH, Leeuw JR, Roovers JP, Heintz AP. The effect of urinary incontinence and overactive bladder symptoms on quality of life in young women. BJU Int. 2002;90(6):544-9.

9. Vaart CH, Leeuw JR, Roovers JP, Heintz AP. Measuring health-related quality of life in women with urogenital dysfunction: the urogenital distress inventory and incontinence impact questionnaire revisited. Neurourol Urodyn. 2003;22(2):97-104.

10. Latthe PM, Foon R, Toozs-Hobson P. Transobturator and retropubic tape procedures in stress urinary incontinence: a systematic review and meta-analysis of effectiveness and complications. BJOG. 2007;114(5):522-31.

11. De RD, Berkers J, Deprest J, Verguts J, Ost D, Hamid D, et al. Single incision mini-sling versus a transobutaror sling: a comparative study on Mini Arc and Monarc slings. Int Urogynecol J Pelvic Floor Dysfunct. 2010;21(7):773-8.

12. Debodinance P, Delporte P. MiniArc. Preliminary prospective study on 72 cases. J Gynecol Obstet Biol Reprod (Paris). 2009;38(2):144-8.

13. Gauruder-Burmester A, Popken G. The Mini Arc sling system in the treatment of female stress urinary incontinence. Int Braz J Urol. 2009;35(3):334-41.

14. Jimenez CJ, Hualde AA, Cebrian Lostal JL, Alvarez BS, Jimenez PJ, Montesino SM, et al. Stress urinary incontinence surgery with MiniArc swing system: our experience. Actas Urol Esp. 2010;34(4):372-7.

15. Kennelly MJ, Moore R, Nguyen JN, Lukban JC, Siegel S. Prospective evaluation of a single incision sling for stress urinary incontinence. $\mathrm{J}$ Urol. 2010;184(2):604-9.

Cite this article as: Goyal N, Goyal SK. Continence outcome following needle less operation (vaginal approach) using indigenous mesh. Int J Reprod Contracept Obstet Gynecol 2016;5:3690-2. 